\title{
Sistem Pendukung Keputusan Kelayakan Kredit pada PT. BPR Mitra Catur Mandiri Menggunakan Metode Credit Scoring
}

\author{
Haris Diyaul Fata*1 ${ }^{*}$ Gita Indah Marthasari ${ }^{2}$, Yufis Azhar ${ }^{3}$ \\ 1,2,3Teknik Informatika/Universitas Muhammadiyah Malang \\ haris.diyaul.fata@gmail.com¹, gita@umm.ac.id², yufis@umm.ac.id ${ }^{3}$
}

\begin{abstract}
Abstrak
Kredit adalah suatu cara yang dapat dilakukan untuk mendapatkan modal usaha. Tetapi terkadang pihak bank mengalami kesulitan dalam melakukan penentuan kredit, hal ini dikarenakan terdapat beberapa kriteria yang tidak terpenuhi oleh calon nasabah. Maka dibutuhkan suatu sistem yang dapat mempermudah petugas bank dalam melakukan penentuan kelayakan kredit, yaitu dengan membangun sistem pendukung keputusan kelayakan kredit menggunakan metode credit scoring. Dalam penentuan kredit, metode credit scoring melakukan perhitungan berdasarkan kriteria-kriteria yang ada, sehingga dapat dihasilkan rekomendasi diterima atau ditolaknya sebuah pengajuan kredit. Berdasarkan penelitian yang telah dilakukan, hasil pembuatan sistem pedukung keputusan kelayakan kredit menggunakan metode credit scoring ini adalah mempermudah petugas bank dalam melakukan penentuan kredit. Berdasarkan pengujian menggunakan metode confusion matrix, sistem ini mempunyai performa yang sangat baik dengan tinggkat akurasi $93 \%$.
\end{abstract}

Kata Kunci: Sistem Pendukung Keputusan, Credit Scoring, Confusion Matrix, Seleksi Penerimaan Kredit

\section{Abstract}

Credit is a way that can be done to obtain business capital. But sometimes the bank has difficulty in determining credit, this is because there are several criteria that are not met by prospective customers. Then a system is needed to facilitate bank officers in determining credit worthiness, namely by building a creditworthiness decision support system using the credit scoring method. In determining credit, the credit scoring method calculates based on existing criteria, so that recommendations can be generated or rejected for a credit proposal. Based on the research that has been done, the results of the creation of a support system for credit feasibility decisions using the credit scoring method is to facilitate bank officers in making credit determinations. Based on testing using the Confusion Matrix method, this system has a very good performance with an accuracy rate of $93 \%$.

Keywords: Decision Support System, Credit Scoring, Confusion Matrix, Credit Receipt Selection

\section{Pendahuluan}

Demi terpenuhinya kebutuhan hidup seseorang, hal yang harus dilakukan adalah dengan usaha. Namun tidak semua orang memiliki modal yang cukup untuk mengembangkan usahanya. Salah satu cara untuk mendapat modal ialah dengan melakukan kredit. Salah satu jenis kredit yang cukup banyak peminatnya saat ini adalah Kredit Usaha Rakyat (KUR), yaitu jenis kredit yang diberikan oleh pemerintah bagi pelaku Usaha, Mikro, Kecil, Menengah dan Koperasi (UMKM-K) di bidang usaha produktif dan layak namun belum bankable [1].

PT. BPR Mitra Catur Mandiri adalah bank yang bergerak dibidang perkreditan. Berbeda dengan bank pada umumnya, Bank Perkreditan Rakyat (BPR) lebih terfokus pada kebutuhan permodalan masyarakat khususnya kalangan menengah ke bawah. Dalam pengajuan kredit, petugas dituntut ketelitian dan kejelian dalam mengambil keputusan diterima atau tidaknya pengajuan kredit, supaya pihak bank tidak mengalami kerugian. Selain itu kendala yang dihadapi bank perkreditan ialah masih terjadinya kredit yang macet, hal ini dikarenakan kesalahan dalam melakukan analisa atau kurang telitinya petugas dalam melakukan analisa kredit. Berdasarkan permasalahan tersebut, maka dibutuhkan suatu sistem pendukung keputusan rekomendasi kelayakan sebuah kredit yang dapat mengoptimalkan proses pemberian putusan kelayakan kredit, serta meminimalisir kesalahan dalam melakukan analisa kredit [2]. Sistem pendukung 
keputusan adalah sistem informasi interaktif yang menyediakan informasi, pemodelan dan manipulasi data. Sistem ini digunakan untuk membantu pengambilan keputusan dalam situasi semi terstuktur dan situasi yang tidak terstruktur, dengan tak seorang pun tahu secara pasti cara keputusan yang seharusnya dibuat [3][4].

Metode yang akan digunakan dalam penelitian ini adalah metode credit scoring. Metode credit scoring dipilih karena metode ini menentukan nilai bobot setiap kriteria yang digunakan dalam penentuan kelayakan pemberian kredit [5]. Luaran hasil skoring didefinisikan sebagai nilai yang tegas yaitu layak atau tidak layak. Diharapkan penilaian akan lebih tepat karena didasarkan pada nilai kriteria dan bobot yang telah ditentukan sebelumnya, yaitu DSC (Debt Serve Coverage Ratio), IDEB (Informasi Debitur), karakter, nilai pinjaman terhadap anggunan, dan lama angsuran. Sehingga akan mendapatkan hasil kelayakan kredit yang lebih akurat.

Dengan adanya sistem pendukung keputusan ini diharapkan dalam penentuan kelayakan sebuah kredit akan lebih baik dan akan meminimalisir kesalahan dalam penentuan kredit.

\section{Metode Penelitian}

Metode penelitian yang digunakan dalam melaksanakan penelitian merupakan dasar penyusunan rancangan penelitian dan merupakan penjelasan dari materi yang telah dipelajari secara umum. Penyelesaian masalah dalam penelitian ini yaitu dengan menggunakan metode penelitian seperti yang dijelaskan pada Gambar 1 .

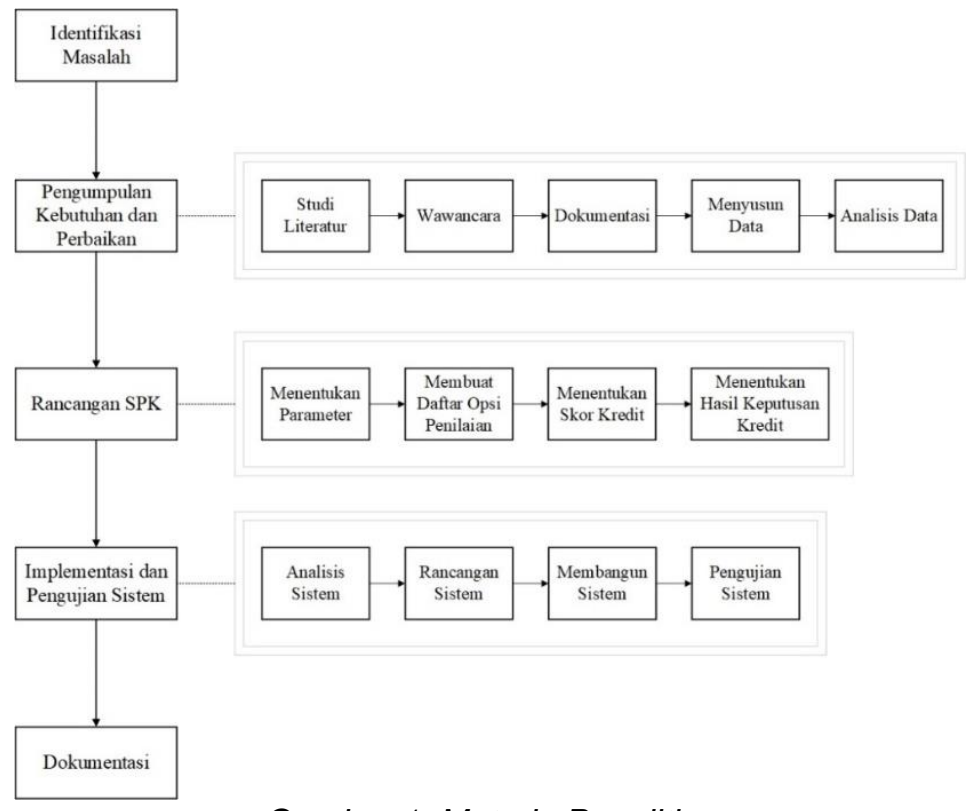

Gambar 1. Metode Penelitian

\subsection{Identifikasi Masalah}

Berdasarkan hasil pengamatan, diperlukan sebuah aplikasi rekomendasi kelayakan kredit yang dapat membantu petugas kredit dalam melakukan penentuan kredit dengan menggunakan metode credit scoring sehingga dapat mengetahui calon nasabah yang layak atau tidak layak untuk mendapatkan kredit dari bank. Maka dari itu penulis melakukan identifikasi masalah sebagai berikut:

1. Belum tersedianya aplikasi yang dapat mempermudah dalam melakukan penentuan kelayakan kredit yang di ajukan calon nasabah kepada bank.

2. Ketersediaan sumber daya yang terbatas misalnya tenaga kerja atau peralatan dan material.

3. Beberapa faktor yang dapat menentukan sebuah kredit dapat dinyatakan layak atau tidak layak.

\subsection{Pengumpulan Kebutuhan dan Perbaikan}

Metode pengumpulan kebutuhan dan perbaikan adalah metode yang digunakan untuk mengumpulkan data yang diperlukan dalam penelitian. Untuk mengumpulkan data-data yang diperlukan, penulis menggunakan beberapa metode diantaranya: 
1. Studi Literatur

Tahapan untuk mengumpulkan dan mengkaji pustaka yang berkaitan dengan penelitian antara lain: kredit, metode credit scoring, waterfall, black box testing, confusion matrix dan pemrograman java. Referensi ini dapat dicari dari buku, jurnal, artikel, laporan penelitian, dan situs-situs di internet.

2. Wawancara

Peneliti melakukan wawancara dengan pihak PT. BPR Mitra Catur Mandiri dalam hal ini adalah bagian kredit. Wawancara yang dilakukan berkaitan dengan data yang dibutuhkan dalam proses pengembangan sistem. Berdasarkan hasil wawancara diketahui bahwa dalam menentukan diterima atau ditolaknya sebuah kredit yaitu berdasarkan kriteria-kriteria seperti, DSC (Debt Serve Coverage Ratio), iDeb (Informasi Debitur), karakter, nilai pinjaman terhadap anggunan, dan lama angsuran.

3. Dokumentasi

Pengumpulan data dengan cara mempelajari dokumen pengajuan kredit yang diajukan oleh calon debitur kepada PT.BPR Mitra Catur Mandiri. Berdasarkan hasil dokumentasi diketahui bahwa terdapat beberapa variabel yang diperoleh yaitu, nama nasabah, pinjaman, lama angsuran, agunan, jenis agunan, landing margin, pendapatan, pengeluaran, iDeb (Informasi debitur), karakter, dan keputusan.

4. Menyusun Data

Penyusunan data yang didapatkan dari hasil wawancara dan dokumentasi yang akan disesuaikan dengan kebutuhan aplikasi rekomendasi kelayakan kredit untuk dilakukan simulasi perhitungan. Data ini dikumpulkan menjadi satu sehingga dapat mempermudah dalam melakukan analisis data. Data yang dimaksud adalah data kriteria untuk menentukan kredit dan variabel yang melekat pada setiap calon debitur.

5. Analisis Data

Tahapan terakhir adalah tahapan analisis terhadap data yang diperoleh untuk menjadi data yang siap untuk diimplementasikan. Dalam analisis data diperlukan kejelian dalam menganalisis data supaya tidak terjadi kendala pada saat implementasi. Hal yang dilakukan dalam analisis data ialah memastikan variabel telah terisi semua dan kesetaraan jenis data pada setiap variabel.

\subsection{Rancangan SPK}

Tahap ini merupakan tahapan untuk merancang suatu sistem pendukung keputusan. Variabel data yang telah tersusun pada tahap sebelumnya digunakan sebagai pola perencanaan awal sebuah sistem. Credit scoring merupakan bagian dari konsep Intelligent Credit Decision Model. Penggunaan teknik scoring/rating dalam pengambilan keputusan kredit diperlukan agar keputusan kredit dapat dilaksanakan secara obyektif karena dilaksanakan berdasarkan sistematika tertentu yang telah baku[6]. Terdapat langkah-langkah yang harus ditentukan yaitu rancangan sistem pendukung keputusan kelayakan kredit berdasarkan metode credit scoring.

1. Menentukan Parameter

Langkah pertama yang harus dilakukan sebelum menerapkan credit scoring pada sistem pendukung keputusan kelayakan kredit yaitu terlebih dahulu menentukan indikator. Indikator tersebut adalah fasilitas kredit, latar belakang, keuangan dan investigasi. Dari indikator-indikator itu maka dikembangkan menjadi parameter yang akan digunakan sebagai penialaian kelayakan kredit. Parameter yang dihasilkan dari indikator-indikator tersebut ialah DSC (Debt Serve Coverage Ratio), iDeb (Informasi Debitur), karakter, nilai pinjaman terhadap anggunan, dan lama angsuran. Indikator penilaian kelayakan kredit dapat dilihat pada Tabel 1.

Tabel 1. Parameter dan Bobot Penilaian Kredit

\begin{tabular}{llrr}
\hline \multicolumn{1}{c}{ Indikator } & \multicolumn{1}{c}{ Parameter } & Kode & Bobot \\
\hline \multirow{2}{*}{ Fasilitas Kredit } & Nilai pinjaman terhadap Anggunan & C4 & $15 \%$ \\
\cline { 2 - 4 } & Lama Angsuran & C5 & $10 \%$ \\
\hline Latar Belakang & Bl Checking (Ideb) & C2 & $25 \%$ \\
Keuangan & DSC (Debt Serve Coverage Ratio) & C1 & $35 \%$ \\
Investigasi & Karakter & C3 & $15 \%$ \\
\hline \multicolumn{2}{c}{ Total } & $100 \%$ \\
\hline
\end{tabular}


2. Membuat Daftar Opsi Penilaian

Merujuk dari indikator dan parameter penilaian kelayakan kredit, maka ditentukan opsi penilaian yang digunakan untuk mempermudah penentuan pemberian skor kredit. Daftar opsi penilaian dari masing-masing parameter ditentukan berdasarkan hasil wawancara terhadap petugas kredit, sehingga penilaian tersebut lebih optimal nantinya. Daftar opsi penilaian dapat dilihat pada Tabel 2.

Tabel 2. Daftar Opsi Penilaian

\begin{tabular}{|c|c|c|c|c|}
\hline Kode & Penilaian & Skor & $\begin{array}{c}\text { Skor Max setiap } \\
\text { Parameter }\end{array}$ & Bobot \\
\hline \multirow{7}{*}{ C1 } & $>2.0$ & 7 & \multirow{7}{*}{7} & \multirow{7}{*}{$35 \%$} \\
\hline & $1.81-2.0$ & 6 & & \\
\hline & $1.61-1.80$ & 5 & & \\
\hline & $1.41-1.60$ & 4 & & \\
\hline & $1.21-1.40$ & 3 & & \\
\hline & $1.01-1.20$ & 2 & & \\
\hline & $<1.0$ & 1 & & \\
\hline \multirow{4}{*}{ C2 } & Lancar & 4 & \multirow{4}{*}{4} & \multirow{4}{*}{$25 \%$} \\
\hline & Kurang Lancar & 3 & & \\
\hline & Diragukan & 2 & & \\
\hline & Macet & 1 & & \\
\hline \multirow{4}{*}{ C3 } & Baik & 4 & \multirow{4}{*}{4} & \multirow{4}{*}{$15 \%$} \\
\hline & Cukup Baik & 3 & & \\
\hline & Kurang Baik & 2 & & \\
\hline & Tidak Baik & 1 & & \\
\hline \multirow{4}{*}{ C4 } & $>160 \%$ & 4 & \multirow{4}{*}{4} & \multirow{4}{*}{$15 \%$} \\
\hline & $141 \%-160 \%$ & 3 & & \\
\hline & $121 \%-140 \%$ & 2 & & \\
\hline & $<121 \%$ & 1 & & \\
\hline \multirow{6}{*}{ C5 } & $31-36$ bulan & 6 & \multirow{6}{*}{6} & \multirow{6}{*}{$10 \%$} \\
\hline & 25 - 30 bulan & 5 & & \\
\hline & $19-24$ bulan & 4 & & \\
\hline & $13-18$ bulan & 3 & & \\
\hline & $7-12$ bulan & 2 & & \\
\hline & $1-6$ bulan & 1 & & \\
\hline
\end{tabular}

3. Menentukan Skor Kredit

Setelah ditentukannya daftar opsi penilaian, pakar kredit memberikan penilaian kelayakan kepada pemohon berdasarkan informasi yang sudah dikumpulkan oleh petugas bank. Kemudian sistem akan menghitung skor dari pemohon kredit dengan menggunakan Persamaan 1 dan Persamaan 2.

$$
\begin{gathered}
N P=\frac{N O}{N M} \times B P \\
\sum_{k=1}^{n} N P_{k}=N P_{1}+N P_{2}+N P_{n}
\end{gathered}
$$

Keterangan:

NP : Nilai parameter

NO : Nilai opsi

NM : Nilai maksimal dari parameter

BP : Bobot parameter 
4. Menentukan Hasil Keputusan Kredit

Setelah skor kredit didapat, tahap selanjutnya adalah menentukan hasil keputusan kredit dimana hasil keputusan nantinya berupa ditolak atau diterimanya suatu kredit berdasarkan ketetapan yang sudah ditentukan sebelumnya dapat dilihat pada Tabel 3.

\section{Tabel 3. Hasil Keputusan Kredit

\begin{tabular}{ll}
\hline \multicolumn{2}{c}{ Keputusan } \\
\hline Diterima & $>0.6$ \\
Ditolak & $\leq 0.6$ \\
\hline
\end{tabular}

\subsubsection{Implementasi dan Pengujian Sistem}

1. Implementasi Sistem

Pada tahap ini akan dilakuan analilis sistem, rancangan sistem, membangun sistem, dan pengujian sistem. Metode yang digunakan adalah waterfall. Model waterfall adalah model pengembangan perangkat lunak. Model ini mengambil kegiatan proses dasar seperti spesifikasi, pengembangan, validasi, dan evolusi, dan mempresentasikannya kedalam fase-fase proses yang berbeda seperti spesifikasi persyaratan, perancangan perangkat lunak, implementasi, pengujian, dan seterusnya [7].

2. Pengujian Sistem

Pada tahap ini juga dilakukan pengujian sistem. Pengujian sistem dilakukan dua kali, yaitu pengujian fungsi sistem (black box testing) dan pengujian hasil perhitungan metode credit scoring menggunakan metode confusion matrix.

\section{1) Black Box Testing}

Black Box Testing adalah metode pengujian perangkat lunak yang berfokus pada spesifikasi fungsional dari sebuah perangkat lunak. Penguji dapat mendefinisikan kumpulan kondisi input dan melakukan pengetesan pada spesifikasi fungsional perangkat lunak apakah sudah sesuai dengan apa yang diharapkan [8].

2) Confusion Matrix

Confusion Matrix adalah metode yang digunakan untuk evaluasi model klasifikasi untuk memperkirakan objek yang benar atau salah. Sebuah matrix dari prediksi yang akan dibandingkan dengan kelas yang asli dari inputan atau dengan kata lain berisi informasi nilai aktual dan prediksi pada klasifikasi [9].

Tabel 4.Confusion Matrix

\begin{tabular}{cccc}
\hline \multirow{2}{*}{ Classification } & \multicolumn{2}{c}{ Predict class } \\
\cline { 3 - 4 } Actual & class $=$ & TP $($ True Positive $)$ & TN $($ True Negative $)$ \\
\cline { 2 - 4 } class & yes & FP (False & FN (False \\
& class $=$ no & Fositive $)$ & Negative) \\
\hline
\end{tabular}
berikut ini:

Evaluasi dan validasi hasil dihitung menggunakan rumus akurasi, precision, dan recall a) Akurasi

Perhitungan akurasi dilakukan dengan cara membagi jumlah data yang diklasifikasikan secara benar dengan total sample data testing yang diuji dengan Persamaan 3.

$$
\text { Akurasi }=\frac{T P+T N}{T P+T N+F P+F N}
$$

\section{b) Precision}

Menghitung nilai precision dengan cara Persamaan 4, yakni membagi jumlah data benar yang bernilai positif (True Positive) dibagi dengan jumlah data benar yang bernilai positif (True Positive) dan data salah yang bernilai positif (False Positive).

$$
\text { Precision }=\frac{T P}{T P+F P}
$$


c) Recall

Sedangkan recall pada Persamaan 5 dengan cara membagi data benar yang bernilai positive (True Positive) dengan hasil penjumlahan dari data benar yang bernilai positif (True Positive) dan data salah yang bernilai negatif (False Negative).

$$
\text { Recall }=\frac{T P}{T P+F N}
$$

\section{Dokumentasi}

Pada tahap ini akan dilakukan proses dokumentasi semua aktivitas penelitian yaitu dari awal penelitian hingga ahir penelitian. Dimana pada tahap ini dilakukan proses penyusunan laporan penelitian yang dijadikan bahan pertanggungjawaban dari penelitian yang telah dikerjakan. Nantinya dalam melakukan proses dokumentasi akan sesuai dengan peraturan yang telah ditentukan pada sistematika penulisan sebelumnya, sehingga laporan yang telah dibuat tidak melenceng dari permasalahan yang menjadi topik penelitian.

\section{Hasil dan Pembahasan}

\subsection{Analisa Sistem}

Aplikasi pendukung keputusan kelayakan kredit dengan metode credit scoring merupakan aplikasi berbasis dekstop yang digunakan sebagai media untuk membantu petugas bank (bagian kredit) dalam melakukan perhitungan kelayakan sebuah kredit yang diajukan oleh calon nasabah, sehingga lebih mudah dalam memberikan informasi pengajuan kredit yang diterima atau ditolak. Aplikasi pendukung keputusan kelayakan kredit ini memiliki pengguna antara lain:

1. Pakar Kredit

Pakar kredit adalah user yang dapat masuk ke dalam sistem aplikasi pendukung keputusan kelayakan kredit. Pakar kredit dapat mengakses beberapa fitur setelah melakukan login dengan hak akses pakar kredit. Suatu inputan yang diberikan oleh seseorang yang ahli/pakar dalam hal kredit sebagai dasar pengetahuan yang digunakan oleh sistem untuk menentukan kelayakan kredit. Data yang di masukkan oleh pakar berupa kriteria yang dipergunakan untuk penentuan kredit serta menentukan nilai bobot setiap kriteria, dan melakukan perhitungan berdasarkan kriteria yang telah ditentukan, sehingga menghasilkan keputusan apakah sebuah kredit layak untuk diterima atau ditolak.

2. Petugas Bank

Petugas bank merupakan user yang dapat masuk ke dalam sistem aplikasi pendukung keputusan kelayakan kredit. Petugas bank dapat mengakses beberapa fitur setelah melakukan login dengan hak akses petugas bank. Petugas bank melakukan kelola data pengajuan kredit.

\subsection{Analisa Kebutuhan}

Analisa kebutuhan bertujuan untuk menganalisa dalam proses pembuatan sistem. Kebutuhan tersebut dibagi menjadi kebutuhan non fungsional dan fungsional.

a. Analisa Kebutuhan Non Fungsional

Pada tahap ini membahas batasan atau layanan yang terdapat pada sistem. Adapun kebutuhan non fungsional yang terdapat pada aplikasi pendukung keputusan kelayakan kredit adalah:

1. Aplikasi pendukung keputusan kelayakan kredit ini merupakan aplikasi berbasis dekstop.

2. Aplikasi pendukung keputusan kelayakan kredit ini merupakan aplikasi yang menggunakan bahasa pemrograman Java dan database Mysql.

3. Aplikasi pendukung keputusan kelayakan kredit ini hanya tersedia offline.

4. Aplikasi pendukung keputusan kelayakan kredit ini merupakan aplikasi yang menerapkan metode credit scoring.

b. Analisa Kebutuhan Fungsional

Pada tahap ini membahas tentang proses dan layanan yang harus disediakan oleh sistem, menjelaskan bagaimana sistem harus bereaksi pada input tertentu dan bagaimana perilaku sistem pada situasi tertentu. Kebutuhan fungsional yang terdapat pada aplikasi pendukung keputusan kelayakan kredit adalah:

1. Sistem menampilkan halaman login yang didalamnya pakar kredit atau petugas bank akan menginputkan username dan password sesuai dengan hak akses untuk bisa masuk ke aplikasi pendukung keputusan kelayakan kredit.

REPOSITOR, Vol. 2, No. 5, Mei 2020: 649-658 
2. Sistem dapat menampilkan data pengajuan kredit, perhitungan credit scoring, dan hasil penentuan kelayakan kredit.

3. Sistem dapat membantu petugas bank untuk mengelola data pengajuan kredit.

4. Sistem dapat membantu pakar kredit untuk perhitungan credit scoring, dan melakukan penentuan apakah kredit layak untuk diterima atau ditolak.

5. Sistem dapat membantu petugas bank dan pakar kredit untuk keluar dari aplikasi pendukung keputusan kelayakan kredit dengan melakukan logout.

6. Sistem melakukan semua penyimpanan data di dalam database.

\subsection{Perancangan Sistem}

Tahapan selanjutnya dari model waterfall adalah rancangan system. Pada tahapan ini bertujuan membuat rancangan dari hasil analisis yang telah dilakukan pada tahap sebelumnya. Informasi, model, dan spesifikasi yang diubah menjadi sebuah desain sistem yang nantinya akan dikodekan.

Data Flow Diagram atau DFD adalah salah satu alat yang digunakan oleh seorang analis sistem. DFD digunakan analis sistem untuk membuat sebuah model sistem yang menunjukkan keterkaitan setiap komponen-komponen sistemnya.Komponen sistem tersebut adalah prosesproses didalam sistem data yang digunakan oleh sistem tersebut, eksternal entitas yang berinteraksi dengan sistem dan aliran data atau informasi di dalam system [10]. Gambar 3 dari DFD untuk sistem pendukung keputusan.

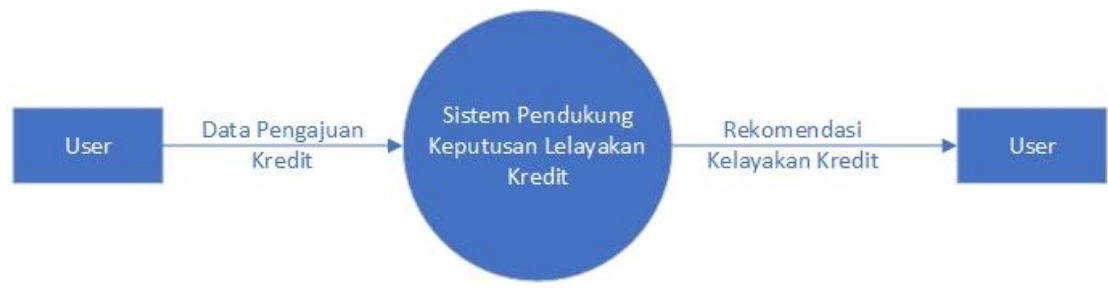

Gambar 2. Konteks Diagram

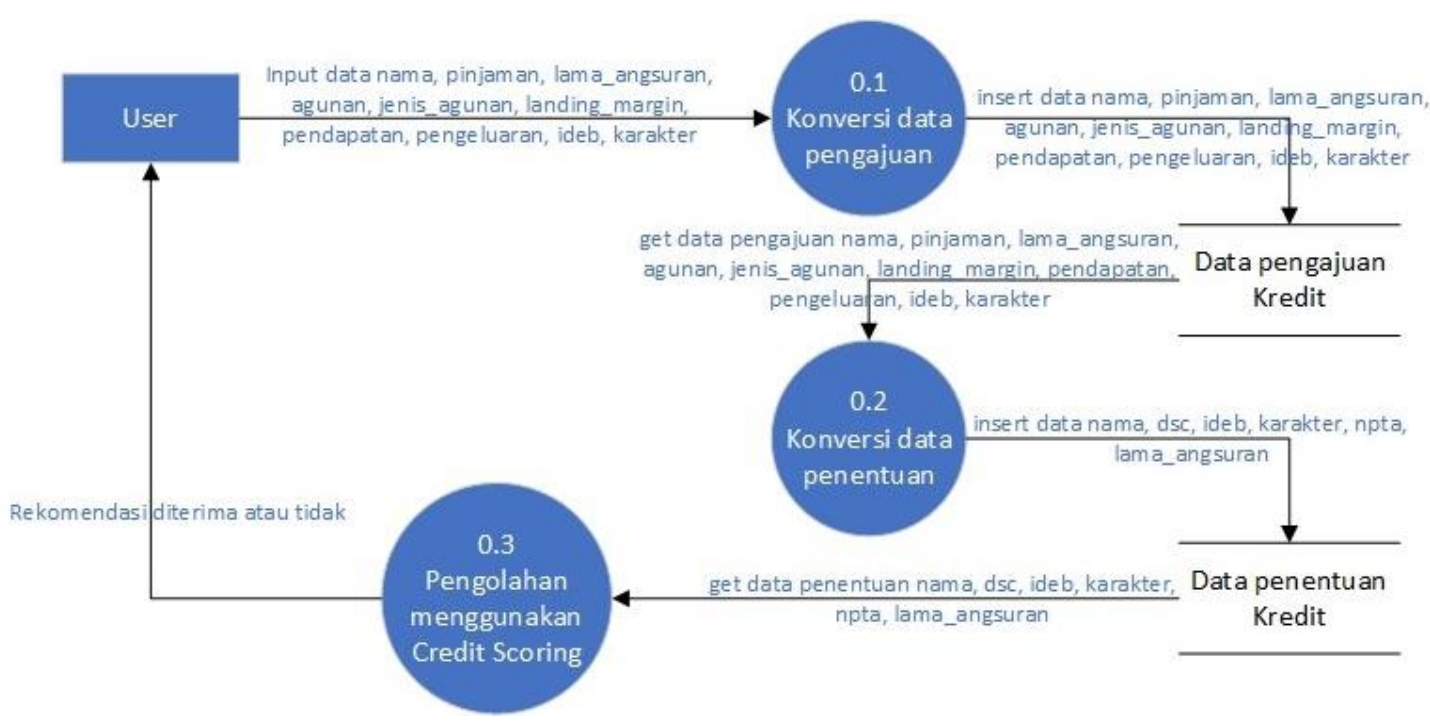

Gambar 3. DFD Level 1

Gambar 2 dan Gambar 3. merupakan gambaran dari alur data yang terdapat pada sistem pendukung keputusan kelayakan kredit. Berikut ini adalah penjelasan dari alur datanya.

1. Peran dari entitas user adalah untuk memberikan masukan berupa data pengajuan kredit, selain itu entitas ini juga berperan menerima informasi dari sistem berupa rekomendasi calon nasabah yang akan diterima atau tidak.

2. Peran dari proses konversi data pengajuan adalah menerima masukan dari entitas user berupa input data. Selanjutnya data akan disimpan ke dalam data pengajuan. 
3. Peran dari proses konversi data penentuan adalah mengambil data dari data pengajuan untuk di konversi menjadi data penentuan. Selanjutnya data akan disimpan ke dalam data penentuan.

4. Peran dari proses pengolahan menggunakan credit scoring adalah mengambil data dari data penentuan kemudian akan dilakukan proses perhitungan menggunakan metode credit scoring, sehingga diperoleh hasil rekomendasi keputusan calon nasabah yang diterima atau ditolak.

5. Data pengajuan digunakan untuk menyimpan data-data pengajuan yang nantinya akan digunakan oleh proses konversi data penentuan.

6. Data penentuan digunakan untuk menyimpan data-data penentuan yang nantinya akan digunakan oleh proses pengolahan menggunakan credit scoring.

\subsection{Implementasi Sistem}

Implementasi sistem adalah salah satu tahapan yang terdapat dalam pengembangan sebuah aplikasi. Pada tahap ini berisi hasil pembuatan sebuah aplikasi, dimana sistem ini dibuat oleh penulis berdasarkan tahapan perancangan sistem yang telah disetujui sebelumnya. Hasil dari pengkodean adalah sebuah antar muka yang dapat dilihat pada pengujian sistem.

\subsection{Pengujian Sistem}

Pengujian sistem merupakan tahapan untuk melakukan pengamatan semua aktivitas input, proses dan output sistem. Pengujian ini dilakukan pada setiap modul atau fungsi selama proses pengembangan. Dalam setiap tahapnya pengujian dilakukan oleh developeryang menulis kode. Pengujian pada penelitian ini menggunkan metode black box testing dan metode confusion matrix.

a. Black Box Testing

Pengujian metode black box testing lebih terfokus pada persyaratan fungsional aplikasi tanpa harus mengetahui struktur internal kode atau aplikasi. Tabel 5 berikut ini adalah hasil dari pengujian menggunakan metode black box testing.

Tabel 5. Pengujian Black Box Testing

\begin{tabular}{|c|c|c|}
\hline Antar Muka & Skenario Pengujian & Hasil Pengujian \\
\hline 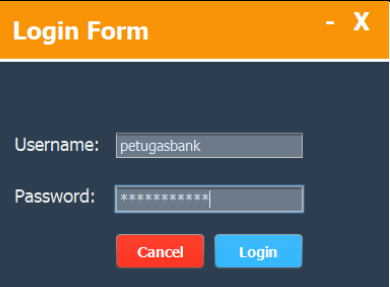 & $\begin{array}{l}\text { Pengguna atau user menginput } \\
\text { username dan password sesuai } \\
\text { dengan hak akses pengguna. } \\
\text { Petugas bank status levelnya } \\
\text { "petugas" sebagai petugas bank. } \\
\text { Pakar kredit status levelnya "pakar" } \\
\text { sebagai pakar kredit. }\end{array}$ & Sukses \\
\hline Home & $\begin{array}{l}\text { Mengklik menu "Home" untuk ke } \\
\text { halaman home. }\end{array}$ & Sukses \\
\hline Lihat & $\begin{array}{l}\text { Mengklik menu "Lihat" untuk ke } \\
\text { halaman Lihat data penentuan. }\end{array}$ & Sukses \\
\hline Tambah & $\begin{array}{l}\text { Mengklik menu "Tambah" untuk ke } \\
\text { halaman tambah data pengajuan. }\end{array}$ & Sukses \\
\hline About & $\begin{array}{l}\text { Mengklik menu "About" untuk ke } \\
\text { halaman about. }\end{array}$ & Sukses \\
\hline 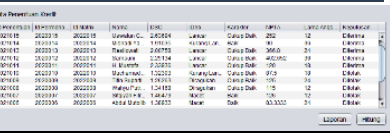 & $\begin{array}{l}\text { Tampilan tabel hasil pengolahan } \\
\text { menggunakan metode credit scoring. }\end{array}$ & Sukses \\
\hline Laporan & $\begin{array}{l}\text { Mengklik menu "Laporan" untuk } \\
\text { menampilkan laporan yang akan } \\
\text { dicetak atau disimpan berdasarkan } \\
\text { hasil keputusan yang dipilih. }\end{array}$ & Sukses \\
\hline
\end{tabular}

REPOSITOR, Vol. 2, No. 5, Mei 2020: 649-658 


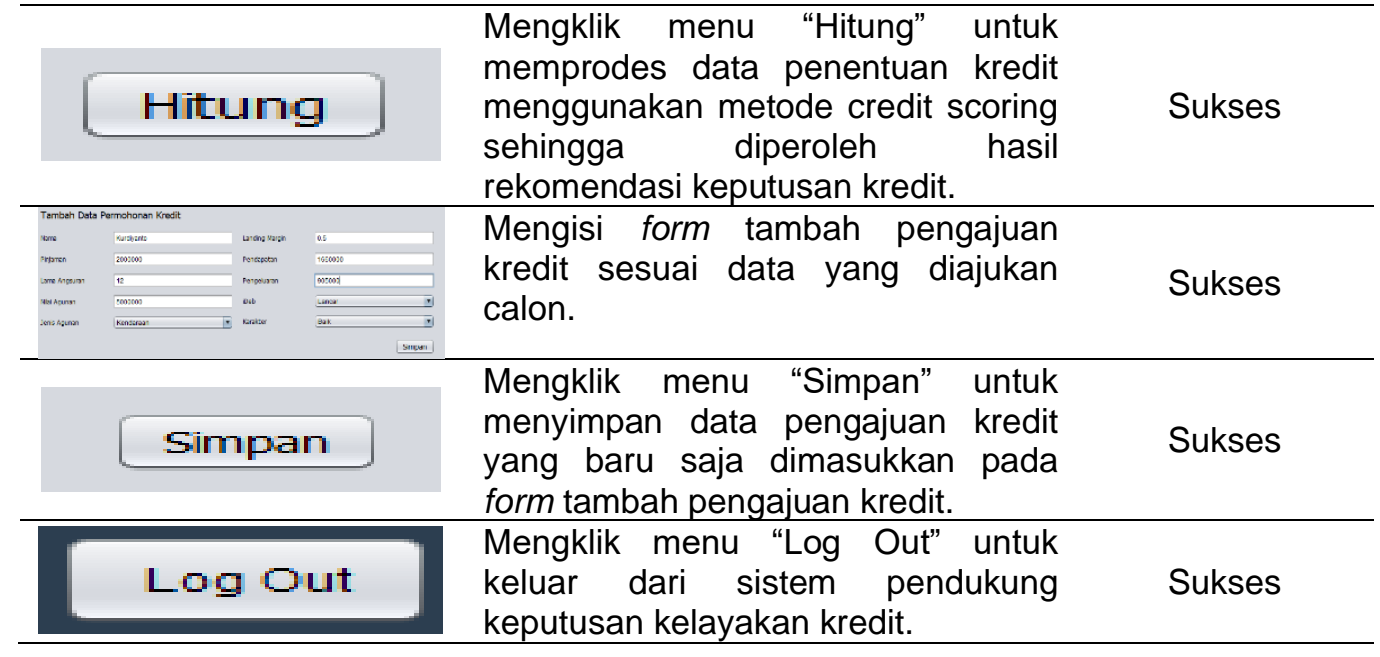

\section{b. Confusion Matrix}

Pengujian menggunakan metode confusion matrix berfokus pada hasil dari keputusan sistem. Dari hasil tersebut akan dibandingkan dengan hasil keputusan oleh pakar. Tabel 6 berikut ini hasil keputusan oleh sistem yang ditampilkan dalam tabel matrix, kemudian akan dihitung menggunakan metode confusion matrix.

Tabel 6. Matrix Hasil Keputusan Sistem

\begin{tabular}{cccc}
\hline \multirow{2}{*}{ Classification } & \multicolumn{2}{c}{ Predict } \\
\cline { 2 - 4 } & & Positive & Negative \\
\hline \multirow{2}{*}{ Actual } & True & 55 & 38 \\
\cline { 2 - 4 } & False & 2 & 5 \\
\hline
\end{tabular}

1. Akurasi

Pada pengujian akurasi akan digunakan Persamaan 6 sebagai berikut.

$$
\begin{gathered}
\text { Akurasi }=\frac{T P+T N}{T P+T N+F P+F N} \\
\text { Akurasi }=\frac{55+38}{55+38+2+5}=\frac{93}{100}=0.93
\end{gathered}
$$

Berdasarkan perhitungan diatas, dapat dinyatakan bahwa tingkat akurasi dari sistem pendukung keputusan kelayakan kredit ini mempunyai tingkat akurasi 0.93 atau $93 \%$.

\section{Presisi}

Pada pengujian presisi akan digunakan Persamaan 7 sebagai berikut.

$$
\begin{gathered}
\text { Precision }=\frac{T P}{T P+F P} \\
\text { Precision }=\frac{55}{55+2}=\frac{55}{57}=0.96491
\end{gathered}
$$

Berdasarkan perhitungan diatas, dapat dinyatakan bahwa tingkat presisi dari sistem pendukung keputusan kelayakan kredit ini mempunyai tingkat presisi 0.96 atau $96 \%$.

\section{Recall}

Pada pengujian recall akan digunakan Persamaan 8 sebagai berikut.

$$
\text { Recall }=\frac{T P}{T P+F N}
$$




$$
\text { Recall }=\frac{55}{55+5}=\frac{55}{60}=0.91667
$$

Berdasarkan perhitungan diatas, dapat dinyatakan bahwa tingkat recall dari sistem pendukung keputusan kelayakan kredit ini mempunyai tingkat recall 0.92 atau $92 \%$.

\section{Kesimpulan}

Berdasarkan penelitian yang telah dilakukan yang dijelaskan pada penjelasan bab sebelumnya mengenai sistem pendukung keputusan kelayakan kredit pada PT. BPR Mitra Catur Mandiri menggunakan metode credit scoring, sistem ini memudahkan pakar kredit dalam melakukan analisa untuk menentukan kelayakan sebuah pengajuan kredit yang diajukan oleh calon nasabah berdasarkan kriteria-kriteria yang ada dan telah ditentukan sebelumnya. Maka dari itu dengan adanya sistem ini akan meringankan kerja pakar dan memper cepat proses penentuan kredit.

Sesuai dengan hasil penelitian dapat disimpulkan bahwa penelitian yang dilakukan oleh penulis berhasil dalam menerapkan metode credit scoring pada sistem pendukung keputusan kelayakan kredit ini. Selain itu, metode credit scoring ini mempunyai performa yang cukup baik sehingga bisa digunakan untuk mendukung suatu keputusan kelayakan kredit pada PT. BPR Mitra Catur Mandiri. Hal ini dibuktikan dengan hasil pengujian yang dilakukan oleh penulis menggunakan metode confusion matrix. Berdasarkan hasil pengujian diperoleh hasil 0.93 atau 93\% untuk tingkat akurasi, 0.96 atau $96 \%$ untuk presisi, dan yang terahir 0.92 atau $92 \%$ untuk recall.

\section{Referensi}

[1] M. Ickhsan, D. Anggraini, R. Haryono, S. H. Sahir, and Rohminatin, "Sistem Pendukung Keputusan Pemberian Kredit Usaha Rakyat ( KUR ) Menggunakan Metode Weighted Product," JURIKOM (Jurnal Ris. Komputer), vol. 5, no. 2, pp. 9-10, 2018.

[2] M. M. S. W. Purnomo, "Fuzzy Logic Sistem Pendukung Keputusan Pemberian Kredit Di Bank Perkreditan Rakyat (BPR) Surabaya," Repos. UNAIR, vol. 1, no. 1, pp. 73-74, 2012.

[3] Y. B. Utomo and J. Ipmawati, "Sistem Pendukung Keputusan Penentuan Penerima Kredit Usaha (Studi Kasus: Adira Finance Kediri)," Creat. Inf. Technol. J., vol. 3, no. 4, p. 295, 2016.

[4] L. H. Siagian, H. Mawengkang, and Z. Situmorang, "Sistem Penunjang Keputusan Pemberian Kredit Menggunakan Logika Fuzzy pada Dealer Sepeda Motor Honda," CESS Unimed, vol. 2, no. 2, pp. 124-128, 2017.

[5] Jumingan, "Pengembangan Model Credit Scoring Untuk Proses Analisis Kelayakan Usaha Para Anggota Koperasi Simpan Pinjam di Kabupaten Sragen (Studi Kasus KSP dan USP)," J. Ilm. Among Makarti, vol. 8, no. 15, pp. 16-24, 2015.

[6] Y. Khusumawardani and R. Ramadhan, "Sistem pendukung keputusan penilaian calon debitur penerima kredit modal kerja bank sultra menggunakan," semanTIK, vol. 2, no. 2, pp. 47-56, 2016.

[7] I. Sommerville, Software Engineering (Rekayasa Perangkat Lunak), 6th ed. Jakarta: Erlangga, 2003.

[8] M. S. Mustaqbal, R. F. Firdaus, and H. Rahmadi, "Pengujian Aplikasi Menggunakan Black Box Testing Boundary Value Analysis," J. Ilm. Teknol. Inf. Terap., vol. I, no. 3, pp. 31-36, 2015.

[9] Y. R. Budi Utami, "Klasifikasi Penentuan Tim Utama Olahraga Hockey Menggunakan Algoritma C4.5," Techno.COM, vol. 15, no. 4, pp. 364-368, 2016.

[10] A. Suryadi, "Sistem Pendukung Keputusan Seleksi Ujian Masuk Perguruan Tinggi Menggunakan Nbc (Naïve Bayes Classifier)," Kinetik, vol. 1, no. 3, pp. 173-182, 2016. 